POLICY BRIEFING SERIES

\title{
iin.
}

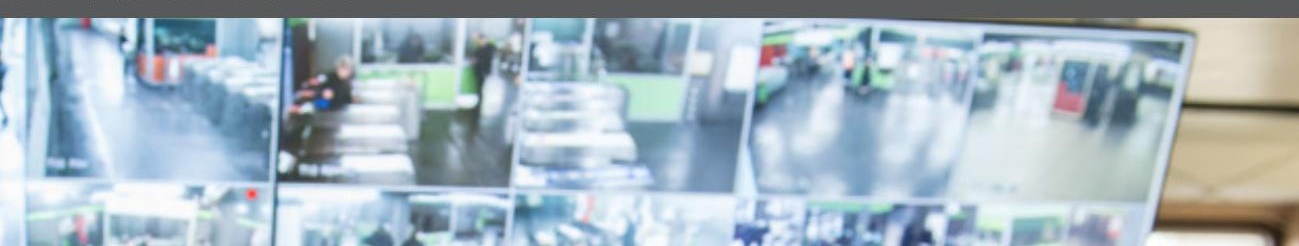

4h a

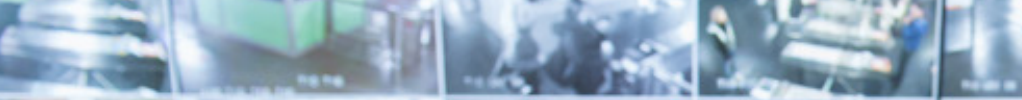

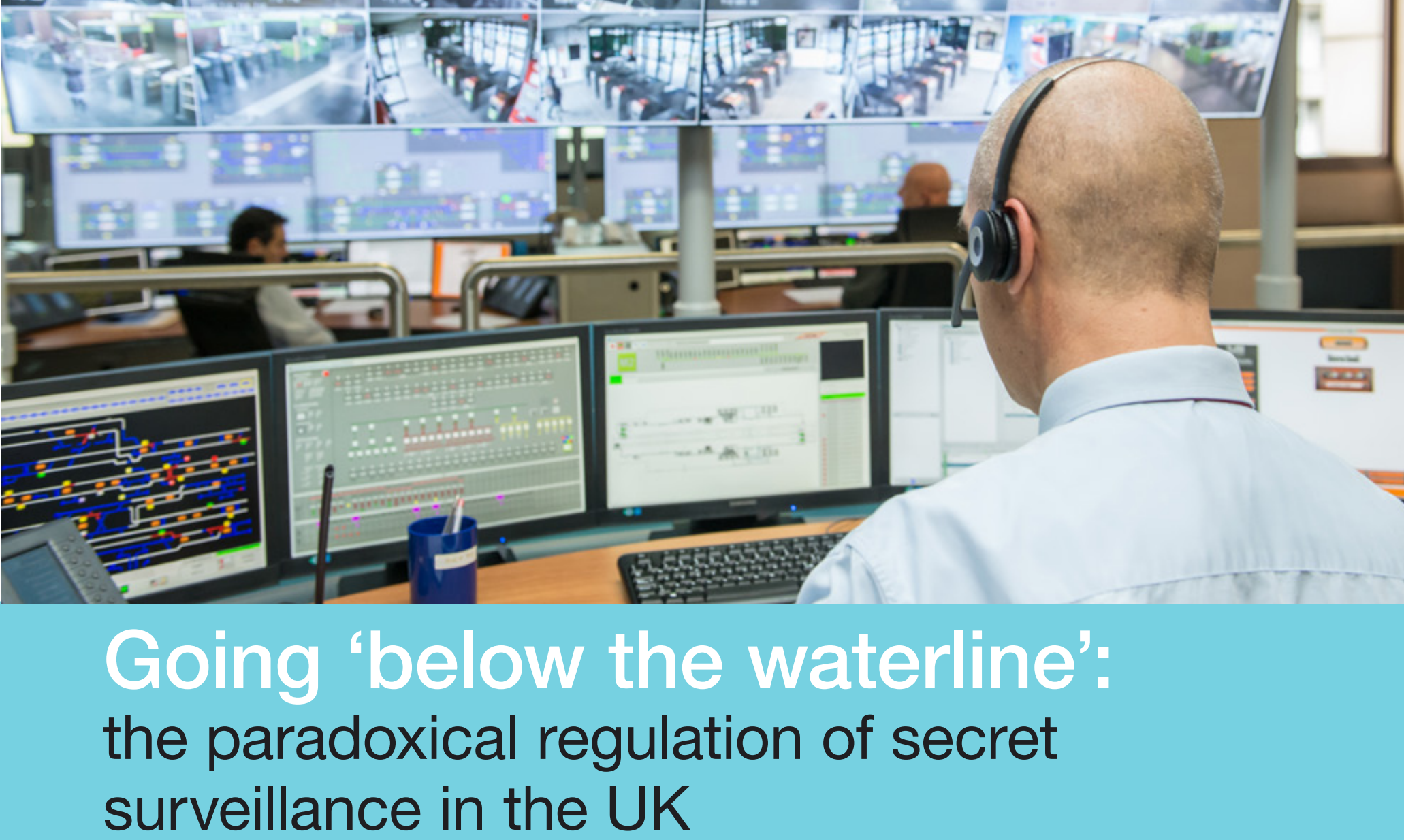

Bernard Keenan 


\section{Going 'below the waterline': the paradoxical regulation of secret surveillance in the UK}

The Investigatory Powers Tribunal recently found that government surveillance was unlawful, marking the first time that the secretive court has ever ruled against the UK's Intelligence Services. Yet the Tribunal also held that the unlawful situation had been remedied by the Tribunal's decision; a paradoxical and unprecedented result that says much about the difficulties of effectively regulating secret activity.

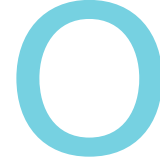

n 6 February 2015 the Investigatory Powers Tribunal (IPT) ruled that until 5 December 2014, the UK Intelligence Services' practice of accessing surveillance information obtained by the United States' spy agency, the NSA, was unlawful. Significantly, 5 December 2014 was the date that the IPT published an interim decision in the case, and that publication made a key difference.

Both sides in the case immediately claimed victory. Privacy International, a member of the coalition of civil liberty organisations that brought the complaint in the aftermath of the Edward Snowden disclosures, celebrated the decision as the first time that a British court has ruled against the Intelligence Services' use of their interception powers. Downing Street and GCHQ, on the other hand, welcomed the decision's confirmation that the UK's current regime is lawful. To the extent that in "one small respect" the program had been unlawful, the government noted, the problem had already been remedied.

This paper makes three key points. First, despite finding illegality on the part of the government, the IPT's decision has substantially lowered existing human rights standards pertaining to state surveillance. Second, the procedures of the IPT blur the line between the judiciary and the executive, conjoining executive and judicial actions in one process. Finally, although the case nominally pertains to privacy, the IPT did not expressly find any violation of privacy nor did it conduct any rigorous review of the actual practices of the Intelligence Services. The ultimate question in this case was to decide how much information about the internal rules of a fundamentally secret system of surveillance must be made public.

\section{Publicity, not privacy}

Historically, the common law did not recognise a right to privacy in the UK. No one had a general right to expect that his or her personal information would be respected by the state under UK law. If officers of the state came to your home to search your papers without a lawful warrant, you had to sue them under the age of telecommunications and the Post Office, where spying could occur invisibly, without trespass, no law protected the privacy of communications. This changed with the growing application of human rights under the European Convention on Human Rights (ECHR), now fully incorporated to domestic law. In the watershed case of Malone $v$ UK (1985) the European Court of Human Rights (ECtHR) held that police phone tapping was a violation of article 8 - the right to privacy - because there was no law authorising the action. If the state is going to eavesdrop on citizens, it first has to create a framework of legislation to authorise and control it. This led to the UK putting its three secret Intelligence Services on a statutory footing (MI5 in 1989, MI6 and GCHQ in 1994). The statutes require all their actions to be ultimately justified by one of three broad headings of national security, economic well-being of the UK, or preventing serious crime, and reviewable by a Parliamentary committee called the Intelligence and Security Committee (ISC).

The key issue in this case was whether or not an acceptable legal framework covers the alleged surveillance practices outlined in Snowden's disclosures. The ECtHR's core requirements for such a framework were outlined in Kennedy v UK:

"First, the impugned [surveillance] measure must have some basis in domestic law. Second, the domestic law must be compatible with the trespass, not privacy. Therefore in rule of law and accessible to the person concerned. Third, the person affected must be able to foresee the consequences of the domestic law for him..."

In other words, the Kennedy case concerns the quality of the law that authorizes the spying. It must be publicly accessible, and the conditions under which eavesdropping can be practiced must be foreseeable. The claimants successfully argued that neither criterion applies to the sharing of intercepted material between the US spy agency NSA and their UK counterpart GCHQ, therefore such sharing is unlawful. A second ground of challenge concerned the adequacy of the UK's existing domestic framework, RIPA, to communication technology in internet age. That ground was rejected by the Tribunal, and is not within the scope of this briefing paper.

The IPT found that there was no publicly accessible framework governing intelligence-sharing, hence any such sharing of intercept material between NSA and GCHQ was unlawful. However, the judgment simultaneously departed from the required standards of accessibility and foreseeability required by the ECtHR in Kennedy. Reasoning that it would be self-defeating to require secret intelligence services to publish its rules and policies in detail, the IPT's test of whether or not the regime is lawful is reformulated at paragraph 37 of the December judgment:

"(i) there must not be an unfettered discretion for executive action. There must be controls on the arbitrariness of that action.

(ii) the nature of the rules must be clear and the ambit of them must be in the public domain so far as possible, an "adequate indication" given (Malone v UK [1985] 7 EHRR 14 at paragraph 67), so that the existence of interference with privacy may in general terms be foreseeable (...)

Consequently, the law must indicate the scope of any such discretion conferred on the competent authorities and the manner of its exercise with sufficient clarity to give the individual adequate protection against arbitrary interference."

This test will be met if (paragraph 41):

"(i) Appropriate rules or arrangements exist and are publicly known and confirmed to exist, with their content 
sufficiently signposted, such as to give an adequate indication of it...

\section{(ii) They are subject to proper oversight."}

Applying this test, the IPT then looked in closed hearings for secret "arrangements" that can be made "publicly known to exist" and their content "sufficiently signposted". The system is already subjected to "proper oversight" by the ISC, the Interception of Communication Commissioner's Office (IOCCO), and of course the IPT. Overall, this is a much lower standard of publicity than that which the ECtHR called for in Kennedy $v$ UK.

Because the legislation that created the IPT contains an ouster clause preventing any party from appealing the case domestically, the claimants have taken the case directly to the ECtHR. If the IPT's new standard is upheld there, then in the long run the government's victory extends far beyond this case. European governments engaged in secret surveillance for the purposes of national security would need only to give vague confirmation that there are secret "arrangements" in place, "signposting" the gist of what those arrangements mean. The public is left to trust that the arrangements are effective, relying on oversight bodies such as the ISC, IOCCO, and indeed the IPT itself to provide second-order confirmation that the arrangements are real, are being applied, and that normal life can continue. This is a legal negotiation over the limits of open government, and it is thus a constitutionally significant issue.

\section{The IPT blurs the separation of powers}

The IPT dealt with this case in both open and closed, i.e. secret, hearings. During closed session, the IPT looked in detail at the secret internal arrangements concerned with intelligence sharing. This led to further disclosure of a summary of secret internal "arrangements", recorded at paragraph 47 of the December judgment. The "disclosure" appears to take the form of written representations by the government's legal team. It is not a separate published document. It does not take the form of a witness statement, unlike other government evidence in the case. Undated, it gives no indication as to when these policies were made, how they are enforced, what training is provided to staff, or anything at all indicative of their quality and efficacy. The disclosure is surprisingly thin, given the weight attached to it by the IPT. In fact, it closely mirrors the government's earlier legal submissions on the point, i.e. that GCHQ treats all intelligence data received from foreign agencies as if it were obtained under the domestic legal framework, the Regulation of Investigatory Powers Act 2000 (RIPA). By framing this as a factual account of what does happen in practice, rather than legal submissions as to what would happen in principle, the government enabled the IPT to view the disclosure as new information, newly admitted to the public domain via the mechanism of the IPT's own written judgment. The performative power of the disclosure was thus determinative of the case. The conclusion on intelligence sharing is that these "arrangements below the waterline" afford adequate protection from abuse, and that they are now made sufficiently clear to the public in summary form such that there is no longer any violation of human rights law.

The Tribunal did not finally determine the matter in December, instead inviting the parties to make sub-missions as to the effect of its initial findings. The ultimate question then was whether or not this meant that the position prior to the 5 December 2014 judgment was unlawful. The second part of the judgment, given on 6 February 2015, found that intelligence sharing had previously been unlawful but is now lawful thanks to the publication of the December judgment. Put like this, the result appears paradoxical: an unlawful situation was rendered lawful by the very process in which its legality was challenged. Of course, it was not the fact of the challenge that made the difference, but rather the disclosure that was published in the decision. Nonetheless, the surprising function of the IPT in this case was simultaneously to provide both the review and the remedy in law. This bears comparison to the most formalistic conception of legality, whereby all that matters normatively is that there is some law in place. It also marks a new dimension of the IPT's inquisitorial status: it not only enquires, it also bridges the secret realm to the public realm.

In so doing, the constitutional separation of powers between the executive and the judiciary is blurred. The executive was acting unlawfully but through collaboration with the judicial process, behind closed doors, it righted the wrong.

\section{No actual violation of privacy was found}

To conclude, it is important to again emphasise that insofar as the government's activities were ruled unlawful, that concerned the publication of their secret internal arrangements. This does not mean that the government was engaged in the worst implications of Snowden's disclosures, such as unlimited mass surveillance, snooping on all of the population, and building a huge database of all of our personal details. In fact the IPT was at pains to say the opposite is the case: that surveillance powers are used only against those who would threaten the security of the UK in some respect. However, the definition of such a threat rests with the executive, acting on secret intelligence advice, and is not subject to judicial review.

Meanwhile, while we await the hearing of the case before the ECtHR, a new government programme of publicising summaries of secret arrangements is already well under way. Government lawyers have made a concession in the on-going Belhaj case before the IPT, conceding that they should have published "arrangements" that ensure intercepted material between lawyers and clients litigating against the government is not passed to the government legal teams fighting the case - a fundamental feature of Legal Professional Privilege necessary for a fair trial. It seems that no such formal arrangements existed, but the government denies that any previous trial has ever been contaminated. The government is also rushing through new policies to protect journalistic sources, aware that the media in particular have a strong interest in these events. But the ultimate problem of trying to balance secrecy and accountability always makes legality itself dependent on some degree of public trust in authority, while at the same time undermining the open basis on which that trust should rest. These are fundamentally political matters that concern the very security of a democratic society. Strasbourg's decision will be watched with great interest around the world.

Bernard Keenan (Department of Law, London School of Economics and Political Science) 


\section{BERNARD KEENAN}

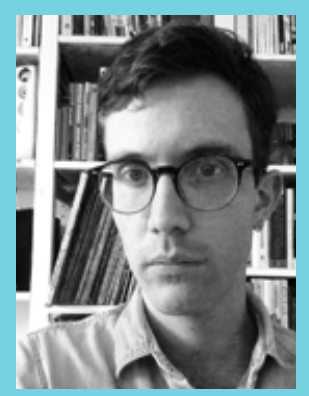

Bernard Keenan is a PhD candidate at the London School of Economics, where he obtained his LL.M in 2008. He researches the use of classified material in legal proceedings in the UK. Before beginning his PhD in 2013, he worked as an immigration lawyer for five years, qualifying as a solicitor.

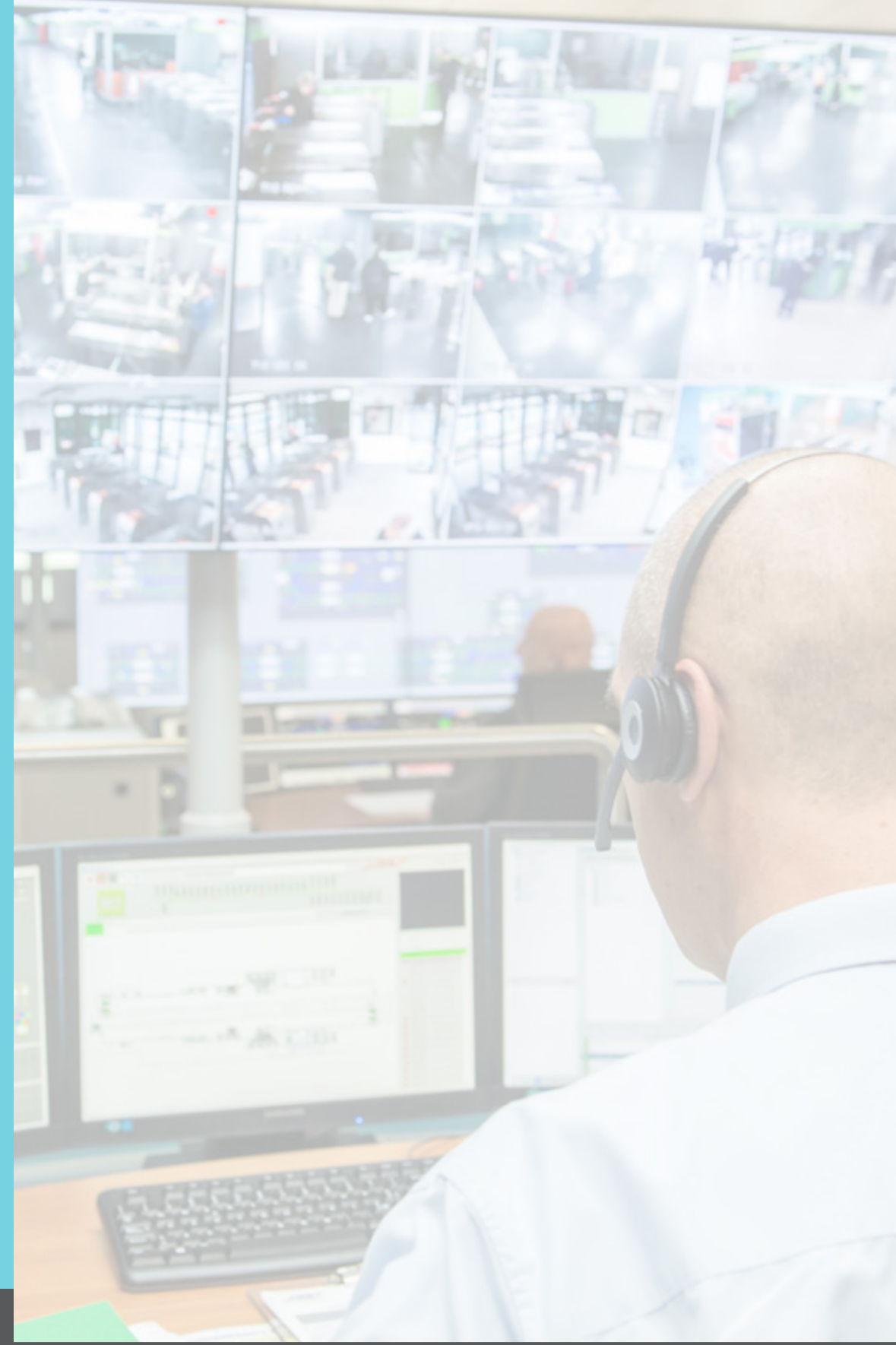

THE LONDON SCHOOL

Department of Law

The London School of Economics

and Political Science

Houghton Street

London WC2A 2AE 